\title{
The Employment Status of the Elderly in Sri Lanka: Emerging Patterns and Determinants
}

\author{
W.G.T.S. Senanayaka and M.H.A. Sisira Kumara \\ University of Sri Jayewardenepura, Sri Lanka
}

\begin{abstract}
By using the Sri Lanka Household Income and Expenditure Surveys in 2002, 2006/2007, and 2009/2010, this paper examines patterns and determinants of employment status of the Sri Lankan elderly. The study employs multinomial logit model to realize the research objectives. The results of the study reveal that more than 50 percent of the Sri Lankan elderly are currently inactive, yet five percent of the oldest elderly and 18 percent of the elderly with bad health conditions are engaged in labour market activities. The results further demonstrate that younger male elderly, who are married and living in femaleheaded households are more likely to be employed than to be inactive. The receipts of remittances, social security payments, and bad health conditions reduce the probability of being employed. At present, ethnicity does not play a significant role in determining employment status of the Sri Lankan elderly.
\end{abstract}

\section{Keywords}

Elderly, Employment Status, Sri Lanka

\section{Introduction}

Current and future demographic trends generate a new pressure on Sri Lanka. This is because regardless of the fact that Sri Lanka's absolute population increases over time, the population growth rate is gradually declining. It has been predicted that particularly the portion of the elderly whose age is 60 years or above will change drastically in the future. For instance, according to De Silva (2007), in 1981 there were one million elderly people in Sri Lanka, who accounted for 6.6 percent of the country's entire population, but this number will increase up to 6.3 million in 2050 accounting for 27.4 percent of the country's total population.

Population projections are essentially concerned with assessing the plausible demographic situations of a country through an understanding of future changes in population size,

\section{Corresponding Author:}

M.H.A. Sisira Kumara, Department of Public Administration, University of Sri Jayewardenepura,

Nugegoda, Sri Lanka. E-mail: mhasisira@sjp.ac.lk 
composition, and distribution. Accordingly, it is important to analyse the pyramid, which demonstrates composition of population in terms of age and gender to explore major changes in the Sri Lankan population in the coming decades. Figure 1 shows the Sri Lankan population pyramid constructed for 1990, 2010, 2030 and 2050 by using the World Population Prospects published by the United Nations in 2010.

As demonstrated in Figure 1, the number of elderly people as a percentage of the total population has been projected to be $8.4,12.3,20.5$, and 27.5 percent in 1990, 2010, 2030, and 2050, respectively. Particularly, the portion of elderly females would be relatively higher than that of elderly males. These changes are primarily caused by the decline in fertility rate and the increase in life expectancy of people in Sri Lanka. Also, the life expectancy of Sri Lankan females is relatively higher than that of Sri Lankan males. As is clear from Figure 1, by 2050 , Sri Lanka will become an aged-economy and resultantly, the pyramid shape of its population structure will disappear. In other words, by 2050, Sri Lanka will have a barrelshaped population structure resulting in numerous socio-economic implications for country's policy-makers.

First, within this context, elderly care needs to be taken into account. Traditionally, family support systems take the responsibility of caring for the elderly in Sri Lanka. However, there is a decline in traditional family support systems for the elderly due to increased levels of rural-urban migration, fewer children to support the elderly, increased female labour force participation, and changes in attitudes and perceptions with regard to elderly care (Vodopivec $\&$ Arunatilake, 2008). This problem has worsened resulting from the limited coverage offered by formal social security systems available for the elderly in Sri Lanka (World Bank, 2007).

Second, in Sri Lanka, old-age dependency ratio increases rapidly to reach 63.4 persons for 100 working-age persons by 2101 from 14.3 in 2001 (De Silva, 2007). Also, due to population aging, people are increasingly withdrawing from the labour force resulting in a shrinking labour force. These trends may impose adverse pressure on economic growth. Thus, policy-makers are required to formulate policies aiming at enhancing elderly welfare, while mitigating negative impacts of population aging on economic growth. Accordingly, this paper basically discusses the employment status of the Sri Lankan elderly with special focus on the patterns and determinants of their status of employment. The findings will enable policymakers to formulate labour market policies that facilitate elderly employment and enhance their welfare. According to the World Bank (2008), effective absorption of the elderly back into the labour force has the possibility of mitigating the adverse impacts of population aging on a country's economic development. Though employment of the Sri Lankan elderly has been the subject of discussion in several other research studies, this study varies from those as it uses three island-wide surveys to analyse both the patterns and the determinants of the employment status of the Sri Lankan elderly, which in turn can be recognized as the strength of this study.

The remainder of the paper is organized as follows: Section 2 presents a review of literature. Then, we will discuss methodology, data and variables in section 3 and 4, respectively. The empirical results and analysis will be presented in section 5, and the final section will conclude the paper by discussing policy implications. 


\section{Review of Literature}

The employment status of the elderly has been the theme of a considerable number of studies, where these studies have examined various aspects of the employment status of the elderly applying different analytical frameworks for different countries. One of the aspects is the relationship between health condition of the elderly and their employment status. For instance, referring to Taiwan, Mete and Schultz (2002) point out that poor health conditions reduce labour force participation of both elderly men and women alike. Their study applied instrumental variable regressions for Taiwanese data collected from 1989 to 1996 although these data had limited coverage of wages, income, and assets of the elderly. A study by Gameren (2008) on the Mexican elderly resulted in similar findings: better health leads to a higher labour force participation rate of the Mexican elderly aged 50 and over. This study employed stage-wise structural regression estimations for data collected from Mexican Health and Aging Study. However, taking endogeneity of elderly health into account, this study found no clear evidence to prove that employment affects the health of the elderly. Further, Kalwij \& Vermeulen (2005) have extended the same theme for 11 European countries. Their results indicated that healthy elderly men's labour force participation rate is higher than unhealthy elderly men's approximately by 10 percentage points in Austria, Germany, and Spain. However, in the Netherlands and Sweden, the same figure is applicable for the female elderly as well.

According to Benitez-Silva (2000), re-employment decision of older Americans depends on certain factors, including physical and mental health, eligibility for disability payments, health and age of the partner, and the preference for joint leisure after retirement. Moreover, the study found that in spite of periodicity, receiving disability payments reduces the probability of being employed after their retirement. Further, in a study on labour force dynamics of elderly married couples in the USA, Blau (1998) found that re-employment probabilities of American elderly depend on employment status of their spouses. Particularly, the study provided strong evidence for a relatively higher likelihood of sharing leisure by elderly couples. Thus, joint retirement is preferred by American elderly couples, and therefore, retirement decision of one spouse depends on the employment status of the other. Also, Deschryvere (2005) in his multinomial logit analysis of the elderly living in Europe argues that husbands' retirement decision is influenced by their wives, exhibiting asymmetric complementarities of leisure. More precisely, his study witnessed that a husband's enjoyment of non-employment might depend more on his wife being non-employed than vice versa.

Blau \& Goodstein (2007) continued with the discourse on elderly employment status by incorporating many socio-demographic and economic variables. Accordingly, they concluded that labour force participation rate of the American elderly depends on changes in social security policies, lifetime earnings, pension coverage, health insurance, and the educational composition of the labour force. This is an exemplary study on labour force participation of the elderly, where it combines micro data from the current population survey with aggregate data from the social security administration. With regard to the same context, Vere (2011) provided econometrics evidence to prove that social security benefits reduce the likelihood of labour force participation after retirement. A study of similar nature has been conducted by Woodland (2007) by using probability choice models for Australia. It found that economic 
variables, such as eligibility for pensions and wage rate, significantly affect labour force participation decision of the Australian elderly. Also, as argued by Kaushal (2014), public pension has imposed a negative impact on the likelihood of labour force participation by Indian male elderly with primary or lower level of education. However, the study has no evidence to show such an impact for similar Indian female elderly.

Using a panel data set on the Japanese elderly for the estimation procedure of multinomial logit models, Raymo et al. (2004) revealed that the socio-economic status and family structure of the elderly significantly affect their transition from one labour force status to another. However, the nature and strength of this relationship depend on both gender and nature of employment of the elderly. For instance, their estimations indicate that occupation in agriculture, presence of a spouse, and living with a married child increase the probability of being self-employed. Interestingly, these variables do not play a significant role in determining the likelihood of being wage-employed. Also, depending on the Indian employment and unemployment surveys, Amireddy (2014) concluded that Indian elderly belonging to relatively poorer socio-economic status are more likely to participate in the labour force.

Moreover, referring to Vietnam household living standard survey, Long \& Pfau (2009) argue that the older elderly, the elderly living in urban areas, the elderly receiving social security benefits, and the elderly living in households with more working-age people are less likely to work irrespective of their gender. Also, their logit estimations indicate that the level of education and receipt of remittances are not significant determinants of the elderly employment status in Vietnam. By employing bivariate analysis for 2007 survey of older persons in Thailand, Adhikari et al. (2011) have concluded that female elderly, widowed and divorced elderly, and elderly living with their children are less likely to be involved in the labour force than their counterparts. However, elderly living in urban areas, elderly with lower level of formal education, and elderly in debt show relatively a larger likelihood of labour force participation. Moreover, some studies have investigated the impact of supplyside factors on the likelihood of elderly labour force participation. For instance, as revealed by Nilsson et al. (2011), the likelihood of labour force participation of Swedish elderly depends on certain supply-side factors including, working environment, working time, and management attitudes towards older workers.

As reviewed thus far, it is clear that the studies of the employment status of the elderly in Sri Lanka are negligible. However, referring to Sri Lanka, Vodopivec \& Arunatilake (2008) argue that previous employment plays a significant role in determining current labour force status of the elderly. They applied multinomial logit models for Sri Lanka Aging Survey conducted in 2006, whereas the strength of their study was that it used a comprehensive set of explanatory variables in the models including labour market factors, family-related factors, and demographic and personal factors. Also, they found that the majority of the Sri Lankan elderly are employed in the informal sector and are poorly paid, and those self-employed elderly have to work until very old age due to poverty. However, this study of Vodopivec \& Arunatilake (2008) was based on a single survey, thus ignoring how labour force status of the Sri Lankan elderly changes over time. 


\section{Methods}

In this study, we employ multinomial logit model to analyse the determinants of the elderly employment status in Sri Lanka from 2002 to 2010. This study defines the elderly as those who are aged 60 years and above. For the purpose of analysing the dynamics and determinants of elderly employment status, we consider three types of the elderly employment status, namely (a) employed, (b) non-employed, and (c) inactive (see Appendix 1). The elderly whose current employment status is "inactive" is considered as the reference category. Accordingly, the standard multinomial logit specifications in relation to this study are elaborated below.

$$
\begin{aligned}
y_{i}= & 1 \text { Employed } \\
& 2 \text { Non - employed } \\
& 3 \text { Inactive }
\end{aligned}
$$

The probability of selecting each employment status is computed as follows:

$$
\begin{aligned}
& \operatorname{Pr}\left(y_{i}=1\right)=\frac{\exp \left(\beta_{1} X\right)}{1+\exp \left(\beta_{1} X\right)+\exp \left(\beta_{2} X\right)} \\
& \operatorname{Pr}\left(y_{i}=2\right)=\frac{\exp \left(\beta_{2} X\right)}{1+\exp \left(\beta_{1} X\right)+\exp \left(\beta_{2} X\right)}
\end{aligned}
$$

The category "inactive"is the reference category, and its probabilityis computed as follows:

$$
\operatorname{Pr}\left(y_{i}=3\right)=\frac{1}{1+\exp \left(\beta_{1} X\right)+\exp \left(\beta_{2} X\right)}
$$

In the above formulation, $\beta_{1}$ and $\beta_{2}$ are the coefficient vector of the first and second outcome, respectively. The vector $\mathrm{X}$ includes explanatory variables considered. The vector $\mathrm{X}$ includes age, gender, marital status, level of education, social security and remittance receipts, ethnicity, living sector and areas of residence, composition and indebtedness of living household, and health condition of the elderly. In order to interpret results, we compute Relative Risk Ratio (RRR), which is defined as the ratio of the probability of selecting one outcome category over the probability of selecting the reference category. When the RRR is greater than unity, the probability of choosing the relevant category is greater than the reference category. Conversely, a RRR, which is less than unity, shows that the probability of choosing the relevant category is lower than the reference category.

\section{Data}

In order to realize research objectives, we used Sri Lanka Household Income and Expenditure Surveys (HIES) conducted in 2002, 2006/2007, and 2009/2010 (namely, HIES 2002, HIES 2006/2007, and HIES 2009/2010, respectively). The HIESs are conducted by the Department of Census and Statistics in Sri Lanka and until the HIES 2006/2007, these household surveys were conducted once in five-years. However, the HIES 2009/2010 was conducted three years after the HIES 2006/2007 with the ending of the country's civil conflict of nearly three decades. The data on demographic characteristics, income and expenditure patterns of individuals were collected through direct personal interviews based on a questionnaire in twelve monthly rounds. Also, from the HIES 2006/2007, data on school education, health, inventory of durable goods, access to basic facilities, indebtedness of households, housing, and agricultural holdings and livestock were collected. 
The HIES 2002 was carried out in all provinces in Sri Lanka except North and East. It gathered information on 71,290 individuals from 16,924 households. However, the HIES 2002 contained data only on 6,926 elderly people, the sample of this study for the HIES 2002 was limited to 6,926 elderly people. Further, HIES 2006/2007 covered all districts except those in the Northern province and Trincomalee district in the Eastern province, covering information on 76,723 individuals from 18,544 households, whereas the HIES 2009/2010, which covered all districts except Mannar, Kilinochchi, and Mullaitivu districts in the Northern province, covered information on 80,853 individuals from 19,958 households. The number of elderly people (sample size) from HIES 2006/2007 and HIES 2009/2010 on which our analyses are based is 8,369 and 9,697 , respectively. In order to make the sample data representative of the entire population in Sri Lanka, the sample data were inflated using the inflation factors provided by each survey. Thus, unless otherwise mentioned, the paper includes weighted estimations. The dependent and independent variables used in the multinomial logit analysis are identified in Appendix 1.

\section{Analysis and Findings The Elderly in Sri Lanka:An Overview}

Table 1 provides useful information on the Sri Lankan elderly in terms of a number of characteristics. Accordingly, apart from minor variations, the structure of the Sri Lankan elderly in terms of their age has not changed considerably over the period from 2002 to 2010. There has been a slight increase in the percentage of the younger elderly (aged 6069), whereas the percentage of the older elderly (aged 70-79) has slightly declined. More specifically, the younger elderly accounted for 56.5 percent in 2002, while it accounted for 60.4 in 2010. Also, the older elderly was 32.4 percent of the total elderly in 2002, but it was only 28.2 percent in 2010 .

In terms of gender, more than 50 percent of the elderly were females in Sri Lanka. This is because the life expectancy of the females is greater than that of males. Particularly, as stated by the Central Bank of Sri Lanka, in 2009 life expectancy at birth for males was 70.3 years and for females this rate was 77.9 years. Also, the majority of the Sri Lankan elderly were married and living in the rural sector of Sri Lanka. In terms of living-provinces, it should be noted that more than one-third of the elderly in Sri Lankan were living in the Western province whereas more than 60 percent of the elderly were living in Western, Central, and Northern provinces during the period concerned.

When considering educational qualifications of the elderly, the percentage of the elderly, who have been schooled only up to the primary level and who have not been schooled, has declined over the period concerned. In contrast, the percentage of the elderly, who have been schooled up to the secondary level, has been increasing gradually over time. For instance, in 2002 , the percentage of the elderly, who have been schooled up to the secondary level was 38.1 percent, and it has increased up to 46.1 percent in 2010. This trend shows that the level of education of the Sri Lankan elderly has increased over time.

Further, we consider three types of social security payments that the Sri Lankan elderly are eligible for, namely pension, disability relief, and Samurdhi payments. Of the elderly, approximately, 30 percent of the elderly were receiving at least one of the aforesaid social security payments in 2002. However, this percentage has reduced up to 27 percent in 2010. 
In other words, constantly over the period from 2002 to 2010, the majority of the elderly have been eligible for none of the social security payments considered. Further, it should be noted that more than 90 percent of the Sri Lankan elderly were not receiving remittances either from local sources or abroad for the period from 2002 to 2010 . When it comes to the health condition, it can be said that more than 50 percent of the Sri Lankan elderly were in good health over the period from 2006 to 2010, which may have been the result of free health services provided by government hospitals throughout the country covering both rural and urban sectors alike. Finally, it is clear from our analysis that in Sri Lanka the majority of the elderly were living in indebted households headed by males over the period concerned.

\section{Patterns of Employment Status of the Sri Lankan Elderly}

Table 2 provides detailed information on three types of elderly employment status, namely employed, non-employed, and inactive. The table shows the percentage of each type of employment status for each value of explanatory variables.

As can be observed in Table 2, the percentage of the employed elderly has decreased from 29.1 percent in 2002 to 25.5 percent in 2010, whereas non-employed and inactive percentages have increased slightly. It should be noted that currently, more than 50 percent of the elderly are inactive in Sri Lanka. More than one-third of the younger elderly have been employed over the period from 2002 to 2010 . However, though 21.6 percent of the older elderly were employed in 2002, this percentage has gradually decreased to 14.5 percent in 2010 . Also, approximately, 10 percent of the oldest elderly were employed in 2002. Nevertheless, this percentage has declined almost by half in 2010. For instance, according to the HIES 2009/2010, only 4.5 percent of the oldest elderly were employed.

In terms of gender, the employed percentage of the male elderly has been predominantly higher than that of the female elderly during the entire period from 2002 to 2009/2010. For instance, 44.7 percent of the male elderly were employed in 2002, but this percentage for the female elderly was 15.1 for the same period. Also, this trend has been constant over the rest of the survey periods concerned. Further, non-employed percentage for the female elderly has been considerably higher than that for the male elderly. Also, it should be highlighted that approximately 50 percent of the elderly have been inactive throughout the period irrespective of their gender. When it comes to marital status, the employed percentage of the married elderly has been larger than that of the non-married elderly. For instance, more than one-third of the married elderly were employed over the period. However, approximately, 20 percent of the non-married elderly were employed in 2002, but it has declined to 13.6 percent in 2010 . It should also be noted that during the entire period concerned, that employed percentage of the Sri Lankan elderly has not changed significantly across different ethnic groups.

The employed percentage has been significantly higher for the rural elderly than their urban counterparts over the period. Also, in terms of provinces, Western province recorded the smallest employed percentage of the elderly, whereas approximately 20 percent of the elderly living in Western province have been employed over the period from 2002 to 2010. In contrast, as can be seen in Table 2, the elderly living in Uva province were more likely to be employed according to both the HIES 2002 and HIES 2009/2010.

Generally, the employed percentage has been declining since 2002 in spite of the level of education of the elderly. For instance, of the elderly with a degree or higher educational 
qualification, 30.8 percent was employed in 2002 . This percentage has gradually declined to 29 percent in 2007 and to 23.7 percent in 2010 . Also, it can be observed that the educated elderly have the trend of being inactive over the period. For instance, inactive percentage of the elderly with a degree or higher educational qualification was 59.9 percent in 2002 , but this has gradually increased up to 68.3 percent in 2010 . However, throughout the entire period, the least employed percentage has been among the elderly with the least level of education (not schooled), while the largest employed percentage has been among the elderly with the highest level of education (degree or above), showing the progressiveness of the level of education and employability of the Sri Lankan elderly.

It is clear from Table 2 that social security payments have discouraged the elderly to be employed. The employed percentage of the elderly, who were receiving social security payments, has been gradually declining since 2002. In 2002, employed percentage of the elderly, who were eligible for social security payments, was 36.1 percent. Nevertheless, it has gradually declined to 26.4 percent in 2007 and to 24.8 percent in 2010 . Also, percentage of inactive among the elderly eligible for social security payments has increased up to 60.1 percent in 2010 from 51.31 percent in 2002. Further, currently, (as evident from the HIES 2009/2010) the elderly employment statuses, including employed, non-employed, and inactive were not significantly varying between the elderly who were receiving remittances and the elderly who were not. However, the employed percentage was higher among the elderly who were receiving remittances according to both the HIES 2002 and HIES 2006/07.

Interestingly, the employed percentage of the elderly living in a male-headed household is relatively greater than that of the elderly living in female-headed households. For instance, the employed percentage among the elderly living in male-headed households is higher approximately by 12 percentage points than that among the elderly living in female-headed households in 2010. Obviously, the employed percentage among the elderly with a good health condition is higher than that among the elderly with a poor health condition. However, it should be noted that of the elderly with a poor health condition, more than 18 percent have been employed during the entire period. Finally, from Table 2, it is clear that the employed percentage of the elderly has not been varying depending on the indebtedness of the households they were living in.

\section{Determinants of the Employment Status of the Sri Lankan Elderly}

In order to explore the determinants of the elderly employment status, we employ multinomial logit model by comparing three employment statuses: employed, non-employed, and inactive. The group of the elderly, who are inactive, is our comparison group. The Relative Risk Ratio (RRR) obtained from multinomial logit analysis is recorded in Table 3(a) and Table 3(b), so that we can compare reference group with other relevant groups. Also, the robust standard error of each estimate is provided in order to show the statistical significance of the estimations.

The estimated relative risk ratios for the age groups of 60-69 and 70-79 are higher than unity and statistically significant in both Table 3(a) and Table 3(b). This basically demonstrates that the younger elderly are more likely to search for employment opportunities, or to be employed rather than to be inactive. Also, gender of the elderly seems to play a significant role in determining their employment status. In Table 3(a), the RRR for the variable gender is greater than unity for the three surveys considered. This simply demonstrates that when 
compared with the female elderly, the male elderly are more likely to be employed than to be inactive. However, as can be observed in Table 3(b), when compared with the female elderly, the male elderly are more likely to be inactive than to be searching for employment opportunities or to be engaged in household activities. In other words, the probability of being employed is relatively lower for the female elderly, whereas the probability of searching for employment opportunities or performing household work is relatively lower for the male elderly in Sri Lanka.

Interestingly, marital status of the elderly has become a significant factor of determining their employment status over the period from 2002 to 2010. The RRR, which is higher than unity in Table 3(a) and Table 3(b) clearly shows that when compared with the elderly who come under the non-married category, the married elderly are more likely to be employed, to search for employment opportunities or to be engaged in household activities than to be inactive. The level of education of the elderly does not seem to be a significant factor of determining whether they are likely to be employed or to be inactive, especially in 2002 . However, in 2010, when compared with the elderly with no schooling, the elderly with a degree or a higher educational qualification have become less likely to be employed than to be inactive. Interestingly, when deciding whether to search for an employment or to be inactive, the level of education has played a significant role over the period. When compared with the elderly with no schooling, the elderly who have been schooled up to primary or secondary level are more likely to search for employment opportunities than to be inactive. Further, generally, when compared with the elderly with no schooling, the elderly with a degree or a higher educational qualification are less likely to search employment opportunities than to be inactive.

Recently, the receipt of remittances and social security payments by the Sri Lankan elderly reduce the probability of the elderly to be employed. It should be noted that in 2002, the receipt of remittances and social security payments were not significant factors of determining the likelihood of being employed or inactive by the elderly. Furthermore, the receipt of social security payments reduces the probability of searching for employment opportunities or being engaged in household activities when compared with the probability of being inactive. Also, over the period, the receipt of remittances by the elderly has no role in determining whether to search for employment opportunities or to be inactive.

Over the period, the elderly living in the urban sector are less likely to be employed than their rural counterparts. The RRR for the variable "living sector" is larger than unity and statistically significant in Table 3(a). However, as is clear from Table 3(b), currently, the decision on whether to search for employment opportunities or to be inactive is not determined by the urban-rural sector. By provinces, currently, when compared with the elderly living in Uva province, the elderly living in Western, Central, Wayamba, and North central provinces are less likely to be employed than to be inactive. Also, recently, when compared with the elderly living in Uva province, the elderly living in other provinces (except for the elderly living in North Central and Sabaragamuwa provinces in 2009/2010) are more likely to search for employment opportunities than to be inactive. In 2002, ethnicity of the elderly was a significant factor of determining their employment status, but recently, the significance of ethnicity in determining elderly employment status has decreased. For instance, currently, the ethnicity is not a vital determinant for the Sri Lankan elderly to choose between the status of 
being employed and inactive, or the status of searching for employment and being inactive.

Further, it can be observed that when compared with the elderly living in female-headed households, the elderly living in male-headed households are less likely to be employed or to search for employment opportunities than to be inactive. Also, poor health conditions of the elderly reduce their probability of being employed or searching for employment opportunities over the period. In other words, poor health conditions have led the elderly to be inactive. The results also show that as a percentage of the household size in which the elderly are living, any increase in the working age household members reduces the probability of the elderly being employed. Currently, the indebtedness of elderly households does not seem to be a significant factor of determining their probability of being employed over being inactive. However, indebtedness of elderly households determines whether the elderly are under the "non-employed" category or the "inactive" category.

\section{Concluding Remarks and Policy Implications}

Sri Lanka is one of the aging societies in the South Asian region. In addressing the issues pertaining to this, the country faces numerous challenges, which are associated with a lack of social security coverage, the trend of decreasing traditional family care of the elderly, and lack of resources to mobilize elderly welfare and health care needs. Further, the World Bank (2008) contends that a country's GDP growth rate is adversely impacted by the decline in labour force resulted from population aging and therefore, recommends formulating policies to encourage elderly employment, an effective measure to addressing issues pertaining to population aging. In the light of this, we conducted this study aiming at exploring the patterns and determinants of the employment status of the Sri Lankan elderly, which was realized by applying multinomial logit analysis for the Sri Lanka Household Income and Expenditure Surveys for 2002, 2006/2007, and 2009/2010.

We found that currently, more than 50 percent of the elderly are inactive, which basically shows that the elderly who have the potential might be out of labour force for some reasons. Further, the employed percentage among the female elderly remains very low. Our multinomial logit analysis also confirms that the probability of searching for employment opportunities or being engaged in unpaid household activities is relatively higher for the female elderly than for the male elderly. This implies that there is both need and potential to absorb the female elderly to the labour force. Increasing levels of investment in primary care-giving facilities, including day-care centres, family support systems, and pre-schools would reduce the burden on the female elderly, who function as primary care givers to their grandchildren in most of the Sri Lankan households (World Bank, 2008). This would encourage the female elderly to be employed in income generation activities.

Though the analysis confirms that poor health conditions reduce the probability of being employed, more than 18 percent of the elderly with poor health conditions are employed in Sri Lanka. This is rather an unfortunate situation and calls for speedy measures to both improve their health condition and to make their economic condition stable, so that they would not have to be involved in paid-employment in old age while suffering from chronic diseases. Public health clinics, regular health check-ups arranged by work places, subsidized health insurance schemes for the elderly, and health workshops aimed at the elderly would enhance the health condition of the elderly. Further, increasing the coverage of social security 
schemes including social pensions and disability relief would make the elderly, especially with poor health, free from working.

Currently, of the oldest elderly (aged 80 and above), approximately five percent is employed. Therefore, from the point of view of their welfare, there is a strong need for appropriate policy initiatives. For instance, until the system of public transportation in Sri Lanka becomes systematic and usable even for the elderly, free transportation can be provided by workplaces for elderly employees. These types of policy would certainly benefit the oldest elderly, who are still working. Further, at workplace level, facilities like escalators and elevators can be arranged, so that elderly employees can easily move between departments/ divisions. However, a wide-ranging social security system would at least make the oldest elderly free from being employed.

Our results confirm that the elderly with a degree or a higher educational qualification are relatively less likely to be employed or to be searching for employment opportunities. This simply implies that those employment opportunities which require higher educational qualifications would absorb a lesser number of the elderly population. Instead those types of employment that can be performed with relatively low educational qualifications like primary and secondary level schooling would absorb more of the elderly population, increasing country's elderly labour force participation rate because the elderly with such qualifications have a relatively higher probability of being employed compared with those elderly with either no educational qualifications or with higher qualifications, such as a university degree. This factor would be important when designing employment for the elderly. Interestingly, ethnicity of the elderly is not a significant factor in determining their employment status. Thus, the policies which either promote or discourage elderly employment need to be implemented irrespective of their ethnicity.

Though the paper provides a number of policy recommendations, they are subject to certain limitations. For instance, this study ignored factors related to Sri Lankan labour market from its analysis. The factors like demand for elderly labour, wage rates, working environment, and labour policy-related matters may have explanatory power, and our future research will address these issues appropriately. Particularly, Sri Lanka Labour Force Survey conducted by the Department of Census and Statistics would be more appropriate than Sri Lanka HIES to incorporate variables related to Sri Lankan labour market in an analysis of the similar nature. 


\section{References}

Adhikari, R., Soonthorndhada, K., \& Haseen, F. (2011). Labor Force Participation in Later Life: Evidence from a cross-sectional study in Thailand. BMC Geriatrics, 11(15), 1-8. doi: 10.1186/1471-2318-11-15

Amireddy, B. R. (2014). Labor Force Participation of Elderly in India. Population Association of America, 2014 Annual meeting program, Boston. Retrieved form: http://paa2014. princeton.edu/papers/141609

Benitez-Silva, H. (2000). Micro Determinants of Labor Force Status among Older Americans. Retrieved form http://ms.cc.sunysb.edu/ hbenitezsilv/conf03.pdf

Blau, D. M. \& Goodstein, R. (2007). What Explains Trends in Labor Force Participation of Older Men in the United States? (Working paper No. 2991). Retrieved from: //www. deutsche-digitale-bibliothek.de/binary/K777VVSBAQS4W7WB2PTGVKG7WXIF6 IL4/full/1.pdf

Blau, D. M. (1998). Labor Force Dynamics of Older Married Couples. Journal of Labor Economics, 16(3), 595-629.

De Silva, W. I. (2007). A Population Projection of Sri Lanka 2001-2101. Colombo: Institute for Health Policy.

Deschryvere, M. (2005). Labor Force Behavior of Men and Women in Elderly: Two-adult households. Evidence from EU Countries. Retrieved from: http://www.etla.fi/wpcontent/uploads/2012/09/dp933.pdf

Gameren, E. V. (2008). Labor Force Participation of Mexican Elderly: The importance of health. Estudios Económicos, 23 (1), 89-127.

Kalwij, A. \& Vermeulen, F. (2005). Labor Force Participation of the Elderly in Europe: The importance of being healthy, (Working paper No. 1887). Retrieved from http://ftp.iza. org/dp1887.pdf

Kaushal, N. (2014). How Public Pension Affects Elderly Labour Supply and Well-being: Evidence from India, World Development, 56(C), 214-225.

Long, G. T. \& Pfau, W. D. (2009). A Gender Perspective on Elderly Work in Vietnam. Retrieved from http://mpra.ub.uni-muenchen.de/24946/4/MPRA_paper_24946.pdf

Mete, C. \& Schultz, T. P. (2002). Health and Labour Force Participation of the Elderly in Taiwan, (Working paper No. 846). New York: Economic Growth Centre.

Nilsson, K., Hydbom, A. R., \& Rylander, L. (2011). Factors Influencing the Decision to Extend Working Life or Retire. Scandinavian Journal of Work, Environment and Health, 37(6), 473-480. doi: 10.5271/sjweh.3181.

Raymo, J. M., Liang, J., Sugisawa, H., Kobayashi, E., \& Sugihara, Y. (2004). Work at Older Ages in Japan: Variation by gender and employment status. Journal of Gerontology: Social Sciences, 59B (3), 154-163.

United Nations. (2010). World Population Prospects-2010. Retrieved from http://www. un.org/en/development/desa/publications/2010.html.

Vere, J. P. (2011). Social Security and Elderly Labor Supply: Evidence from the health and retirement study. Labour Economics, (18), 676-686.

Vodopivec, M. \& Arunatilake, N. (2008). The Impact of Population Aging on the Labour Market: The case of Sri Lanka (Working paper No. 3456). Colombo: The Institute for the Study of Labor. 
Woodland, A. D. (2007). Determinants of the Labor Force Status of the Aged. Economic Record, 63(2), 97-114.

World Bank. (2007). Sri Lanka: Strengthening social protection. Retrieved from http:// siteresources.worldbank.org/INTSOUTHASIA/Resources/Strengthening_Social_ Protection.pdf

World Bank. (2008). Sri Lanka Addressing the Needs of an Aging Population. Retrieved from http://www-wds.worldbank.org/external/default/WDSContentServer/WDSP/IB/2008/ 07/08/000334955_20080708084333/Rendered/PDF/433960ESW0P09410gray0cover0 1PUBLIC1.pdf 
Table 1: Main Characteristics of Sri Lankan Elderly: Percentage of Total Elderly Population

\begin{tabular}{|c|c|c|c|}
\hline Survey Period & 2002 & $2006 / 2007$ & $2009 / 2010$ \\
\hline $\begin{array}{l}\text { Age } \\
60-69 \\
70-79 \\
80 \text { over }\end{array}$ & $\begin{array}{l}56.51 \\
32.35 \\
11.14\end{array}$ & $\begin{array}{l}57.90 \\
30.21 \\
11.89\end{array}$ & $\begin{array}{l}60.38 \\
28.20 \\
11.42\end{array}$ \\
\hline $\begin{array}{l}\text { Gender } \\
\text { Male } \\
\text { Female } \\
\end{array}$ & $\begin{array}{l}47.27 \\
52.73 \\
\end{array}$ & $\begin{array}{l}44.52 \\
55.48 \\
\end{array}$ & $\begin{array}{l}45.41 \\
54.59 \\
\end{array}$ \\
\hline $\begin{array}{l}\text { Marital Status } \\
\text { Married } \\
\text { Non-married }\end{array}$ & $\begin{array}{l}61.83 \\
38.17\end{array}$ & $\begin{array}{l}59.25 \\
40.75\end{array}$ & $\begin{array}{l}59.56 \\
40.44\end{array}$ \\
\hline $\begin{array}{l}\text { Ethnicity } \\
\text { Sinhala } \\
\text { Tamil } \\
\text { Other }\end{array}$ & $\begin{array}{l}87.29 \\
7.85 \\
4.86\end{array}$ & $\begin{array}{l}85.20 \\
8.76 \\
6.04\end{array}$ & $\begin{array}{l}81.40 \\
12.08 \\
6.52\end{array}$ \\
\hline $\begin{array}{l}\text { Living sector } \\
\text { Urban } \\
\text { Rural }\end{array}$ & $\begin{array}{l}14.05 \\
85.95\end{array}$ & $\begin{array}{l}14.47 \\
85.53\end{array}$ & $\begin{array}{l}15.47 \\
84.53\end{array}$ \\
\hline $\begin{array}{l}\text { Province } \\
\text { Western } \\
\text { Central } \\
\text { Southern } \\
\text { Northern } \\
\text { Eastern } \\
\text { Wayamba } \\
\text { North Central } \\
\text { Uva } \\
\text { Sabaragamuwa }\end{array}$ & $\begin{array}{l}34.52 \\
14.86 \\
16.83 \\
\text { n.d. } \\
\text { n.d. } \\
12.73 \\
4.62 \\
4.97 \\
11.47\end{array}$ & $\begin{array}{l}33.92 \\
14.77 \\
15.61 \\
\text { n.d. } \\
2.82 \\
11.29 \\
4.48 \\
5.65 \\
11.46\end{array}$ & $\begin{array}{l}33.44 \\
14.22 \\
14.37 \\
3.16 \\
4.17 \\
11.00 \\
4.18 \\
5.29 \\
10.17\end{array}$ \\
\hline $\begin{array}{l}\text { Educational Qualification } \\
\text { No } \\
\text { Primary } \\
\text { Secondary } \\
\text { Degree or higher }\end{array}$ & $\begin{array}{l}16.24 \\
44.00 \\
38.05 \\
1.71\end{array}$ & $\begin{array}{l}14.35 \\
43.18 \\
40.32 \\
2.15\end{array}$ & $\begin{array}{l}12.33 \\
39.51 \\
46.05 \\
2.11\end{array}$ \\
\hline $\begin{array}{l}\text { Social Security Receipts } \\
\text { Yes } \\
\text { No }\end{array}$ & $\begin{array}{l}30.74 \\
69.26 \\
\end{array}$ & $\begin{array}{l}31.25 \\
68.75 \\
\end{array}$ & $\begin{array}{l}27.24 \\
72.76 \\
\end{array}$ \\
\hline $\begin{array}{l}\text { Remittance Receipts } \\
\text { Yes } \\
\text { No }\end{array}$ & $\begin{array}{l}5.61 \\
94.39\end{array}$ & $\begin{array}{l}6.91 \\
93.09\end{array}$ & $\begin{array}{l}7.63 \\
92.37\end{array}$ \\
\hline $\begin{array}{l}\text { Gender of household head } \\
\text { Male } \\
\text { Female }\end{array}$ & $\begin{array}{l}75.72 \\
24.28\end{array}$ & $\begin{array}{r}74.10 \\
25.90 \\
\end{array}$ & $\begin{array}{l}74.85 \\
25.15 \\
\end{array}$ \\
\hline $\begin{array}{l}\text { Health Condition } \\
\text { Bad } \\
\text { Good }\end{array}$ & $\begin{array}{l}\text { n.d. } \\
\text { n.d. }\end{array}$ & $\begin{array}{l}44.47 \\
55.53\end{array}$ & $\begin{array}{l}43.81 \\
56.19\end{array}$ \\
\hline $\begin{array}{l}\text { Indebtedness of living household } \\
\text { Indebted } \\
\text { Not indebted }\end{array}$ & $\begin{array}{l}\text { n.d. } \\
\text { n.d. }\end{array}$ & $\begin{array}{r}51.63 \\
48.37 \\
\end{array}$ & $\begin{array}{l}50.37 \\
49.63 \\
\end{array}$ \\
\hline
\end{tabular}

Source: Own calculations based on HIES 2002, HIES 2006/2007, and HIES 2009/2010 of Sri Lanka

Note:

n.d.=no data 
THE EMPLOYMENT STATUS OF THE ELDERLY IN SRI LANKA

Table 2: Statistical Summary of Elderly Employment Status of Sri Lanka: As a Percentage of Each Category of Independent Variable Values

\begin{tabular}{|c|c|c|c|c|c|c|c|c|c|}
\hline & \multicolumn{3}{|c|}{2002} & \multicolumn{3}{|c|}{$2006 / 2007$} & \multicolumn{3}{|c|}{$2009 / 2010$} \\
\hline & Employed & Non-employed & Inactive & Employed & Non-employed & Inactive & Employed & Non-employed & Inactive \\
\hline Sample size (n) & 6,926 & & & 8,369 & & & 9,697 & & \\
\hline $\begin{array}{l}\text { Percentage of elderly } \\
\text { population }\end{array}$ & 29.08 & 21.30 & 49.62 & 25.37 & 20.65 & 53.98 & 25.47 & 22.34 & 52.19 \\
\hline \multicolumn{10}{|l|}{ Age } \\
\hline $60-69$ & $37.14^{*}$ & $27.33^{*}$ & $35.53^{*}$ & $34.56^{*}$ & $27.19^{*}$ & $38.25 *$ & $34.56^{*}$ & $29.12 *$ & $36.32 *$ \\
\hline $70-79$ & $21.62^{*}$ & $15.47 *$ & $62.91^{*}$ & $16.18^{*}$ & $14.17^{*}$ & $69.65^{*}$ & $14.48 *$ & $14.41 *$ & $71.11^{*}$ \\
\hline 80 over & $9.94 *$ & $7.62 *$ & $82.44 *$ & $3.95^{*}$ & $5.31 *$ & $90.74 *$ & $4.50^{*}$ & $6.13^{*}$ & $89.37 *$ \\
\hline \multicolumn{10}{|l|}{ Gender } \\
\hline Male & $44.67^{*}$ & $5.93 *$ & 49.40 & $42.99^{*}$ & $3.51 \%$ & 53.50 & $41.98^{*}$ & $5.37 *$ & $52.65^{*}$ \\
\hline Female & $15.11^{*}$ & $35.08^{*}$ & 49.81 & $11.23^{*}$ & $34.42^{*}$ & 54.35 & $11.73^{*}$ & $36.46^{*}$ & $51.81 *$ \\
\hline \multicolumn{10}{|l|}{ Marital Status } \\
\hline Married & $34.82 *$ & 20.78 & $44.40^{*}$ & $33.49^{*}$ & $19.24^{*}$ & $47.27 *$ & $33.50 *$ & $21.35^{*}$ & $45.15^{*}$ \\
\hline Non-married & $19.79 *$ & 22.15 & $58.06^{*}$ & $13.55^{*}$ & $22.72 *$ & $63.73^{*}$ & $13.62 *$ & $23.81 *$ & $62.57 *$ \\
\hline \multicolumn{10}{|l|}{ Ethnicity } \\
\hline Sinhala & 29.83 & $22.06^{*}$ & $48.11^{*}$ & 25.89 & $20.95^{*}$ & $53.16^{*}$ & 25.71 & 21.93 & 52.36 \\
\hline Tamil & 23.77 & $14.21^{*}$ & $62.02 *$ & 23.15 & $16.62^{*}$ & $60.23^{*}$ & 24.63 & 23.71 & 51.66 \\
\hline Other & 24.26 & $19.15^{*}$ & $56.59^{*}$ & 21.19 & $22.45^{*}$ & $56.36^{*}$ & 23.92 & 25.00 & 51.08 \\
\hline \multicolumn{10}{|l|}{ Living sector } \\
\hline Urban & $17.88^{*}$ & $25.49^{*}$ & $56.63^{*}$ & $17.00^{*}$ & $27.01 *$ & 55.99 & $18.64^{*}$ & $24.50 *$ & $56.86^{*}$ \\
\hline Rural & $30.93^{*}$ & $20.62 *$ & $48.47 *$ & $26.79^{*}$ & $19.58^{*}$ & 53.63 & $26.71^{*}$ & $21.95^{*}$ & $51.34 *$ \\
\hline \multicolumn{10}{|l|}{ Province } \\
\hline Western & $21.92^{*}$ & $24.40^{*}$ & $53.68^{*}$ & $20.00^{*}$ & $25.29 *$ & $54.71^{*}$ & $20.55^{*}$ & $23.78^{*}$ & 55.67 \\
\hline Central & $30.23^{*}$ & $18.89^{*}$ & $50.88^{*}$ & $24.33^{*}$ & $19.18^{*}$ & $56.49^{*}$ & $25.99^{*}$ & $21.83^{*}$ & 52.18 \\
\hline Southern & $34.16^{*}$ & $21.59^{*}$ & $44.25^{*}$ & $29.59^{*}$ & $19.43 *$ & $50.98^{*}$ & $25.83^{*}$ & $24.17 *$ & 50.00 \\
\hline Northern & n.d. & n.d. & n.d. & n.d. & n.d. & n.d. & $23.78^{*}$ & $33.09 *$ & 43.13 \\
\hline Eastern & n.d. & n.d. & n.d. & $27.73^{*}$ & $22.90^{*}$ & $49.37 *$ & $25.96^{*}$ & $28.95^{*}$ & 45.09 \\
\hline Wayamba & $34.06^{*}$ & $22.52 *$ & $43.42 *$ & $27.65^{*}$ & $23.50^{*}$ & $48.85^{*}$ & $28.57 *$ & $21.70 *$ & 49.73 \\
\hline
\end{tabular}

Continued 
Table 2: Statistical Summary of Elderly Employment Status of Sri Lanka: As a Percentage of Each Category of Independent Variable Values

\section{Continued}

\begin{tabular}{|c|c|c|c|c|c|c|c|c|c|}
\hline \multirow[b]{3}{*}{ North Central } & \multicolumn{3}{|c|}{2002} & \multicolumn{3}{|c|}{$2006 / 2007$} & \multicolumn{3}{|c|}{$2009 / 2010$} \\
\hline & Employed & Non-employed & Inactive & Employed & Non-employed & Inactive & Employed & Non-employed & Inactive \\
\hline & $30.02 *$ & $18.55^{*}$ & $51.43^{*}$ & $35.38^{*}$ & $16.95^{*}$ & $47.67 *$ & $31.12^{*}$ & $17.67 *$ & 51.21 \\
\hline Uva & $41.17 *$ & $12.59^{*}$ & $46.24 *$ & $27.54 *$ & $7.71 *$ & $64.75^{*}$ & $35.08^{*}$ & $12.97 *$ & 51.95 \\
\hline Sabaragamuwa & $30.59^{*}$ & $18.20^{*}$ & $51.21^{*}$ & $29.03 *$ & $14.99 *$ & $55.98 *$ & $30.54 *$ & $17.04 *$ & 52.42 \\
\hline \multicolumn{10}{|l|}{$\begin{array}{l}\text { Educational } \\
\text { Qualification }\end{array}$} \\
\hline No & $21.75^{*}$ & $18.57 *$ & $59.68 *$ & $13.66^{*}$ & $15.14^{*}$ & $71.20 *$ & $18.55^{*}$ & $16.82 *$ & $64.63 *$ \\
\hline Primary & $30.23 *$ & $20.86^{*}$ & $48.91^{*}$ & $27.40 *$ & $18.62 *$ & $53.98 *$ & $25.51^{*}$ & $21.23^{*}$ & $52.26 *$ \\
\hline Secondary & $30.81^{*}$ & $23.52^{*}$ & $45.67^{*}$ & $27.25^{*}$ & $25.42 *$ & $47.33^{*}$ & $27.40^{*}$ & $25.40 *$ & $47.20 *$ \\
\hline Degree or higher & $30.78^{*}$ & $9.29 *$ & $59.93 *$ & $29.04 *$ & $9.13 *$ & $61.83^{*}$ & $23.65^{*}$ & $8.14^{*}$ & $68.21 *$ \\
\hline \multicolumn{10}{|l|}{$\begin{array}{l}\text { Social Security } \\
\text { Receipts }\end{array}$} \\
\hline Yes & $36.14^{*}$ & $12.55^{*}$ & $51.31 *$ & 26.37 & $14.40^{*}$ & $59.23 *$ & $24.76^{*}$ & $15.12 *$ & $60.12 *$ \\
\hline No & $25.96^{*}$ & $25.18^{*}$ & $48.86^{*}$ & 24.91 & $23.50^{*}$ & $51.58 *$ & $25.73^{*}$ & $25.04 *$ & $49.23 *$ \\
\hline \multicolumn{10}{|c|}{ Remittance Receipts } \\
\hline Yes & $40.93 *$ & $14.33^{*}$ & 44.74 & $31.64 *$ & 16.80 & 51.57 & 26.07 & 19.14 & 54.79 \\
\hline No & $28.38 *$ & $21.72 *$ & 49.90 & $24.90 *$ & 20.94 & 54.15 & 25.41 & 22.61 & 51.98 \\
\hline \multicolumn{10}{|c|}{$\begin{array}{l}\text { Gender of household } \\
\text { head }\end{array}$} \\
\hline Male & $30.50^{*}$ & $20.18^{*}$ & 49.32 & $28.47 *$ & $17.71^{*}$ & 53.82 & $28.60 *$ & $20.18^{*}$ & $51.22 *$ \\
\hline Female & $24.67 *$ & $24.78^{*}$ & 50.55 & $16.49 *$ & $29.09^{*}$ & 54.42 & $16.14^{*}$ & $28.78^{*}$ & $55.08 *$ \\
\hline \multicolumn{10}{|l|}{ Health Condition } \\
\hline Bad & n.d. & n.d. & n.d. & $18.46 *$ & 20.30 & $61.23^{*}$ & $18.88^{*}$ & $21.71 *$ & $59.41 *$ \\
\hline Good & n.d. & n.d. & n.d. & $30.90 *$ & 20.94 & $48.15^{*}$ & $30.60 *$ & $22.84 *$ & $46.56^{*}$ \\
\hline
\end{tabular}

Continued 
Table 2: Statistical Summary of Elderly Employment Status of Sri Lanka: As a Percentage of Each Category of Independent Variable Values Continued

\begin{tabular}{|c|c|c|c|c|c|c|c|c|c|}
\hline & \multicolumn{3}{|c|}{2002} & \multicolumn{3}{|c|}{$2006 / 2007$} & \multicolumn{3}{|c|}{$2009 / 2010$} \\
\hline & Employed & Non-employed & Inactive & Employed & Non-employed & Inactive & Employed & Non-employed & Inactive \\
\hline $\begin{array}{l}\text { Indebtedness } \\
\text { household }\end{array}$ & & & & & & & & & \\
\hline Indebted & n.d. & n.d. & n.d. & 24.87 & 19.67 & $55.46 *$ & 25.50 & $20.91 *$ & $53.59 *$ \\
\hline Not indebted & n.d. & n.d. & n.d. & 25.90 & 21.71 & $52.39 *$ & 25.43 & $23.80^{*}$ & $50.77^{*}$ \\
\hline
\end{tabular}

Source: Own calculations based on HIES 2002, HIES 2006/2007, and HIES 2009/2010 of Sri Lanka

Note:

* indicates that the differences of each category of elderly employment status across independent variable categories are statistically significant at 5\% error level.

n.d.=no data 
Table 3(a): Relative Risk Ratio (RRR) from Multinomial Logit Estimation: "Employed" Vs. "Inactive"

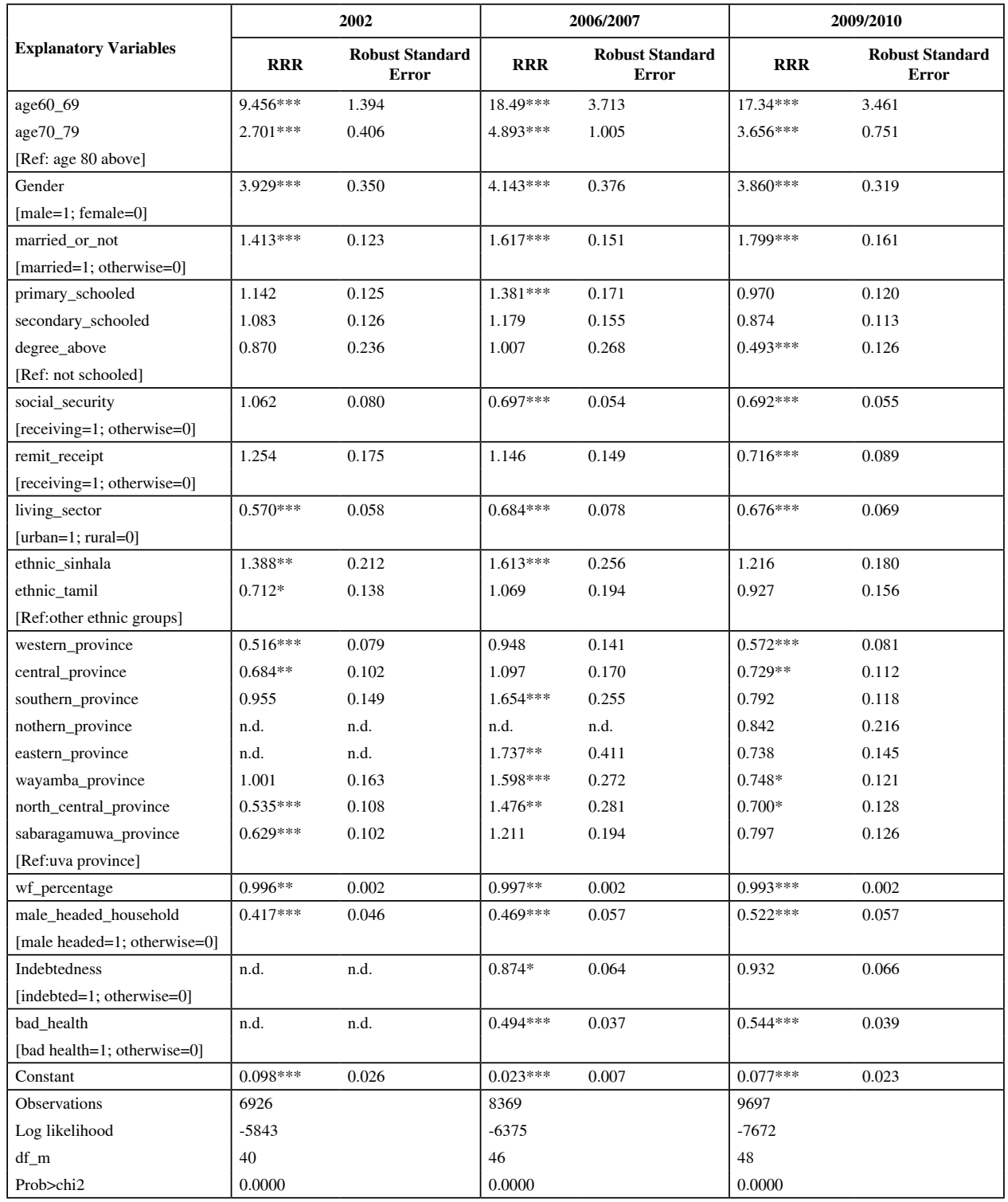

Source: Own calculations based on HIES 2002, HIES 2006/2007, and HIES 2009/2010 of Sri Lanka

Note:

$* * *$ indicates statistical significance at $1 \%$ error level; ** indicates statistical significance at $5 \%$ error level; * indicates statistical significance at $10 \%$ error level 
THE EMPLOYMENT STATUS OF THE ELDERLY IN SRI LANKA

Table 3(a): Relative Risk Ratio (RRR) from Multinomial Logit Estimation: "Employed" Vs. "Inactive"

\begin{tabular}{|c|c|c|c|c|c|c|}
\hline \multirow[b]{2}{*}{ Explanatory Variables } & \multicolumn{2}{|c|}{2002} & \multicolumn{2}{|c|}{$2006 / 2007$} & \multicolumn{2}{|c|}{$2009 / 2010$} \\
\hline & RRR & $\begin{array}{c}\text { Robust Standard } \\
\text { Error }\end{array}$ & RRR & $\begin{array}{c}\text { Robust Standard } \\
\text { Error }\end{array}$ & RRR & $\begin{array}{c}\text { Robust Standard } \\
\text { Error }\end{array}$ \\
\hline age60_69 & $9.456 * * *$ & 1.394 & $18.49 * * *$ & 3.713 & $17.34 * * *$ & 3.461 \\
\hline $\begin{array}{l}\text { age } 70 \_79 \\
\text { [Ref: age } 80 \text { above] }\end{array}$ & $2.701 * * *$ & 0.406 & $4.893 * * *$ & 1.005 & $3.656 * * *$ & 0.751 \\
\hline $\begin{array}{l}\text { Gender } \\
{[\text { male }=1 ; \text { female }=0]}\end{array}$ & $3.929 * * *$ & 0.350 & $4.143 * * *$ & 0.376 & $3.860 * * *$ & 0.319 \\
\hline $\begin{array}{l}\text { married_or_not } \\
{[\text { married }=1 ; \text { otherwise }=0]}\end{array}$ & $1.413 * * *$ & 0.123 & $1.617 * * *$ & 0.151 & $1.799 * * *$ & 0.161 \\
\hline primary_schooled & 1.142 & 0.125 & $1.381^{* * *}$ & 0.171 & 0.970 & 0.120 \\
\hline secondary_schooled & 1.083 & 0.126 & 1.179 & 0.155 & 0.874 & 0.113 \\
\hline $\begin{array}{l}\text { degree_above } \\
\text { [Ref: not schooled] }\end{array}$ & 0.870 & 0.236 & 1.007 & 0.268 & $0.493 * * *$ & 0.126 \\
\hline $\begin{array}{l}\text { social_security } \\
{[\text { receiving }=1 ; \text { otherwise }=0]}\end{array}$ & 1.062 & 0.080 & $0.697 * * *$ & 0.054 & $0.692 * * *$ & 0.055 \\
\hline $\begin{array}{l}\text { remit_receipt } \\
{[\text { receiving }=1 ; \text { otherwise }=0]}\end{array}$ & 1.254 & 0.175 & 1.146 & 0.149 & $0.716^{* * *}$ & 0.089 \\
\hline $\begin{array}{l}\text { living_sector } \\
{[\text { urban }=1 ; \text { rural }=0]}\end{array}$ & $0.570 * * *$ & 0.058 & $0.684 * * *$ & 0.078 & $0.676^{* * *}$ & 0.069 \\
\hline $\begin{array}{l}\text { ethnic_sinhala } \\
\text { ethnic_tamil } \\
\text { [Ref:other ethnic groups] }\end{array}$ & $\begin{array}{l}1.388 * * \\
0.712 *\end{array}$ & $\begin{array}{l}0.212 \\
0.138\end{array}$ & $\begin{array}{l}1.613^{* * *} \\
1.069\end{array}$ & $\begin{array}{l}0.256 \\
0.194\end{array}$ & $\begin{array}{l}1.216 \\
0.927\end{array}$ & $\begin{array}{l}0.180 \\
0.156\end{array}$ \\
\hline $\begin{array}{l}\text { western_province } \\
\text { central_province } \\
\text { southern_province } \\
\text { nothern_province } \\
\text { eastern_province } \\
\text { wayamba_province } \\
\text { north_central_province } \\
\text { sabaragamuwa_province } \\
\text { [Ref:uva province] }\end{array}$ & $\begin{array}{l}0.516 * * * \\
0.684 * * \\
0.955 \\
\text { n.d. } \\
\text { n.d. } \\
1.001 \\
0.535 * * * \\
0.629 * * *\end{array}$ & $\begin{array}{l}0.079 \\
0.102 \\
0.149 \\
\text { n.d. } \\
\text { n.d. } \\
0.163 \\
0.108 \\
0.102\end{array}$ & $\begin{array}{l}0.948 \\
1.097 \\
1.654 * * * \\
\text { n.d. } \\
1.737 * * \\
1.598^{* * *} \\
1.476^{* *} \\
1.211\end{array}$ & $\begin{array}{l}0.141 \\
0.170 \\
0.255 \\
\text { n.d. } \\
0.411 \\
0.272 \\
0.281 \\
0.194\end{array}$ & $\begin{array}{l}0.572 * * * \\
0.729 * * \\
0.792 \\
0.842 \\
0.738 \\
0.748^{*} \\
0.700 * \\
0.797\end{array}$ & $\begin{array}{l}0.081 \\
0.112 \\
0.118 \\
0.216 \\
0.145 \\
0.121 \\
0.128 \\
0.126\end{array}$ \\
\hline $\begin{array}{l}\text { wf_percentage } \\
\text { male_headed_household } \\
\text { [male headed }=1 ; \\
\text { otherwise }=0 \text { ] }\end{array}$ & $\begin{array}{l}0.996 * * \\
0.417 * * *\end{array}$ & $\begin{array}{l}0.002 \\
0.046\end{array}$ & $\begin{array}{l}0.997 * * \\
0.469 * * *\end{array}$ & $\begin{array}{l}0.002 \\
0.057\end{array}$ & $\begin{array}{l}0.993 * * * \\
0.522 * * *\end{array}$ & $\begin{array}{l}0.002 \\
0.057\end{array}$ \\
\hline $\begin{array}{l}\text { Indebtedness } \\
{[\text { indebted }=1 ; \text { otherwise }=0]}\end{array}$ & n.d. & n.d. & $0.874 *$ & 0.064 & 0.932 & 0.066 \\
\hline $\begin{array}{l}\text { bad_health } \\
{[\text { bad health }=1 ; \text { otherwise }=0 \text { ] }}\end{array}$ & n.d. & n.d. & $0.494 * * *$ & 0.037 & $0.544 * * *$ & 0.039 \\
\hline Constant & $0.098 * * *$ & 0.026 & $0.023^{* * *}$ & 0.007 & $0.077 * * *$ & 0.023 \\
\hline Observations & 6926 & 8369 & 9697 & & & \\
\hline Log likelihood & -5843 & -6375 & -7672 & & & \\
\hline df_m & 40 & 46 & 48 & & & \\
\hline Prob $>$ chi 2 & 0.0000 & 0.0000 & 0.0000 & & & \\
\hline
\end{tabular}

Source: Own calculations based on HIES 2002, HIES 2006/2007, and HIES 2009/2010 of Sri Lanka

Note:

$* * *$ indicates statistical significance at $1 \%$ error level; ** indicates statistical significance at $5 \%$ error level; $*$ indicates statistical significance at $10 \%$ error level

n.d. $=$ no data 
Table 3(b): Relative Risk Ratio (RRR) from Multinomial Logit Estimation: "Nonemployed" Vs. "Inactive"

\begin{tabular}{|c|c|c|c|c|c|c|}
\hline \multirow[b]{2}{*}{ Explanatory Variables } & \multicolumn{2}{|c|}{2002} & \multicolumn{2}{|c|}{$2006 / 2007$} & \multicolumn{2}{|c|}{$2009 / 2010$} \\
\hline & RRR & $\begin{array}{c}\text { Robust } \\
\text { Standard Error }\end{array}$ & RRR & $\begin{array}{c}\text { Robust } \\
\text { Standard Error }\end{array}$ & RRR & $\begin{array}{c}\text { Robust } \\
\text { Standard Error }\end{array}$ \\
\hline age60_69 & $7.838 * * *$ & 1.295 & $11.91 * * *$ & 2.199 & $10.23 * * *$ & 1.693 \\
\hline $\begin{array}{l}\text { age } 70 \_79 \\
\text { [Ref: age } 80 \text { above] }\end{array}$ & $2.624 * * *$ & 0.447 & $3.493 * * *$ & 0.666 & $2.821 * * *$ & 0.486 \\
\hline $\begin{array}{l}\text { Gender } \\
{[\text { male }=1 ; \text { female }=0]}\end{array}$ & $0.153 * * *$ & 0.017 & $0.084 * * *$ & 0.011 & $0.122 * * *$ & 0.013 \\
\hline $\begin{array}{l}\text { married_or_not } \\
{[\text { married }=1 ; \text { otherwise }=0]}\end{array}$ & $1.353 * * *$ & 0.136 & $1.544 * * *$ & 0.173 & $1.356^{* * *}$ & 0.137 \\
\hline primary_schooled & $1.535^{* * *}$ & 0.176 & $1.653 * * *$ & 0.207 & $1.560 * * *$ & 0.191 \\
\hline secondary_schooled & $1.669^{* * *}$ & 0.203 & $2.325 * * *$ & 0.307 & $1.957 * * *$ & 0.245 \\
\hline $\begin{array}{l}\text { degree_above } \\
\text { [Ref: not schooled] }\end{array}$ & $0.434 * *$ & 0.158 & 0.536 & 0.213 & $0.460 * *$ & 0.146 \\
\hline $\begin{array}{l}\text { social_security } \\
{[\text { receiving }=1 ; \text { otherwise }=0]}\end{array}$ & $0.576 * * *$ & 0.057 & $0.643 * * *$ & 0.064 & $0.605 * * *$ & 0.055 \\
\hline $\begin{array}{l}\text { remit_receipt } \\
{[\text { receiving }=1 ; \text { otherwise }=0]}\end{array}$ & 1.083 & 0.194 & 1.021 & 0.186 & 1.097 & 0.152 \\
\hline $\begin{array}{l}\text { living_sector } \\
{[\text { urban=1; rural }=0]}\end{array}$ & 1.077 & 0.106 & $1.251 * *$ & 0.142 & 0.895 & 0.082 \\
\hline $\begin{array}{l}\text { ethnic_sinhala } \\
\text { ethnic_tamil } \\
\text { [Ref:other ethnic groups] }\end{array}$ & $\begin{array}{l}1.419^{* *} \\
0.644^{*}\end{array}$ & $\begin{array}{l}0.248 \\
0.145\end{array}$ & $\begin{array}{l}1.133 \\
0.792\end{array}$ & $\begin{array}{l}0.199 \\
0.159\end{array}$ & $\begin{array}{l}0.953 \\
0.790\end{array}$ & $\begin{array}{l}0.143 \\
0.135\end{array}$ \\
\hline western_province & 1.363 & 0.296 & $3.697 * * *$ & 0.794 & $1.566^{* *}$ & 0.284 \\
\hline central_province & 1.308 & 0.291 & $3.181 * * *$ & 0.709 & $1.768 * * *$ & 0.343 \\
\hline southern_province & $1.533^{*}$ & 0.345 & $3.775 * * *$ & 0.842 & $1.912 * * *$ & 0.365 \\
\hline nothern_province & n.d. & n.d. & n.d. & n.d. & $3.395 * * *$ & 0.982 \\
\hline eastern_province & n.d. & n.d. & $5.882 * * *$ & 1.731 & $2.845^{* * *}$ & 0.687 \\
\hline wayamba_province & $1.769^{* *}$ & 0.416 & $4.357^{* * *}$ & 1.019 & $1.548^{* *}$ & 0.317 \\
\hline north_central_province & 0.888 & 0.244 & $2.495^{* * *}$ & 0.661 & 1.197 & 0.276 \\
\hline $\begin{array}{l}\text { sabaragamuwa_province } \\
\text { [Ref:uva province] }\end{array}$ & 1.088 & 0.256 & $2.347 * * *$ & 0.555 & 1.106 & 0.226 \\
\hline wf_percentage & 0.998 & 0.002 & 0.998 & 0.002 & $0.995 * * *$ & 0.002 \\
\hline $\begin{array}{l}\text { male_headed_household } \\
{[\text { male headed }=1 ; \text { otherwise }=0]}\end{array}$ & 1.073 & 0.114 & $0.711^{* * *}$ & 0.079 & 0.960 & 0.099 \\
\hline $\begin{array}{l}\text { Indebtedness } \\
{[\text { indebted }=1 ; \text { otherwise }=0]}\end{array}$ & n.d. & n.d. & $0.840^{* *}$ & 0.067 & $0.832 * *$ & 0.061 \\
\hline $\begin{array}{l}\text { bad_health } \\
{[\text { bad health }=1 ; \text { otherwise }=0]}\end{array}$ & n.d. & n.d. & $0.765^{* * *}$ & 0.061 & $0.801 * * *$ & 0.057 \\
\hline Constant & $0.0623^{* * *}$ & 0.020 & $0.022^{* * *}$ & 0.008 & $0.0796^{* * *}$ & 0.023 \\
\hline Observations & 6926 & & 8369 & & 9697 & \\
\hline Log likelihood & -5843 & & -6375 & & -7672 & \\
\hline df_m & 40 & & 46 & & 48 & \\
\hline Prob $>$ chi 2 & 0.0000 & & 0.0000 & & 0.0000 & \\
\hline
\end{tabular}

Source: Own calculations based on HIES 2002, HIES 2006/2007, and HIES 2009/2010 of Sri Lanka

Note:

$* * *$ indicates statistical significance at $1 \%$ error level; $* *$ indicates statistical significance at $5 \%$ error level; * indicates statistical significance at $10 \%$ error level

n.d.=no data 
Figure 1: Population Pyramids of Sri Lanka
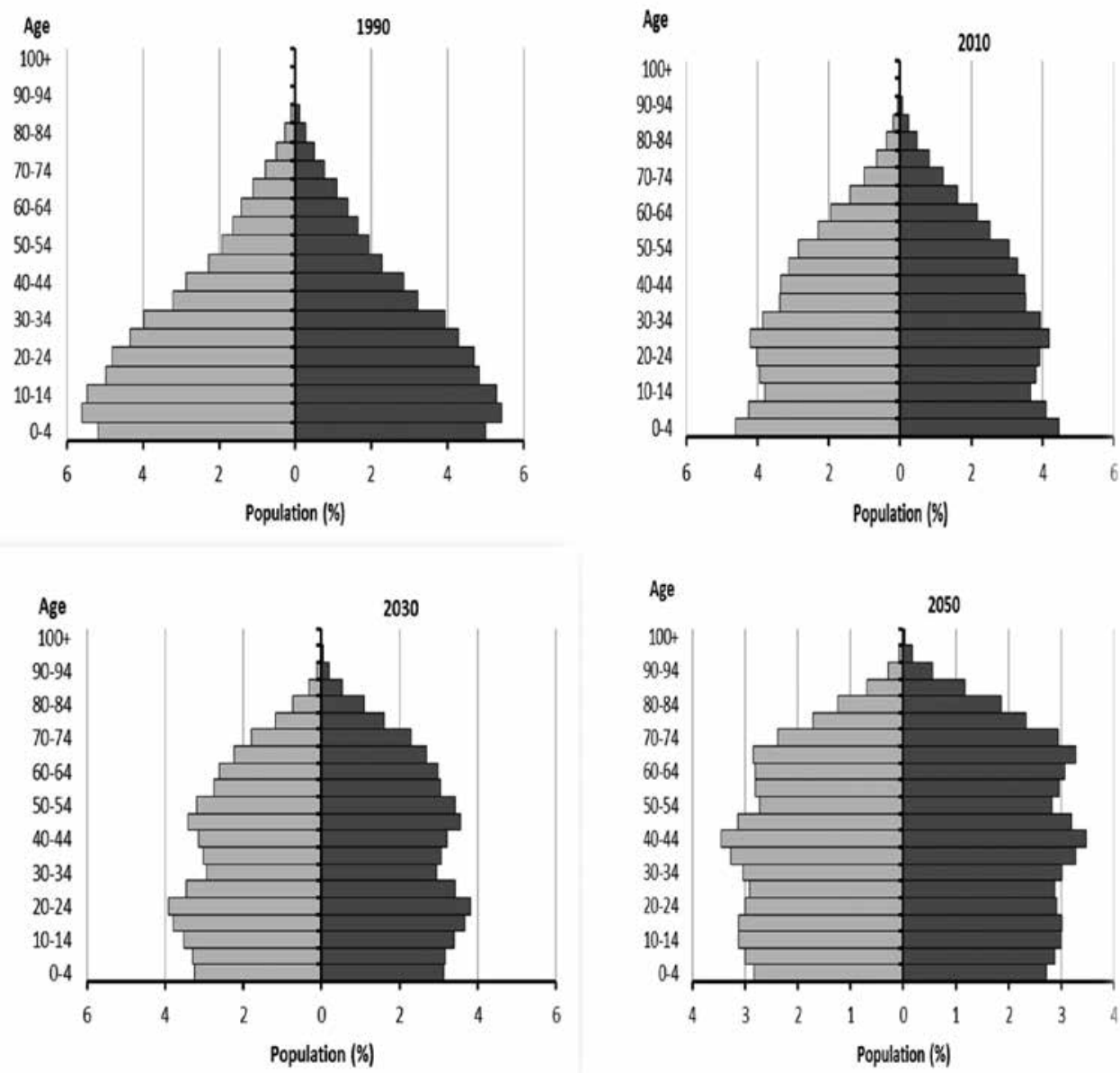

Male

Female

Source: Own computations based on world population prospects by the United Nations, the 2010 revision. 


\section{Appendix 1: Descriptions for Independent and Dependent Variables}

\begin{tabular}{|c|c|}
\hline Variable & Description \\
\hline $\begin{array}{l}\text { Employment status of } \\
\text { elderly }\end{array}$ & $\begin{array}{l}\text { We consider three categories of employment status of the elderly. The category } \\
\text { "employed" includes the elderly who are currently employed as an employee or an } \\
\text { employer. The category "non-employed" includes the elderly who are looking for an } \\
\text { employment opportunity and are engaged in household work. Finally, the category } \\
\text { "inactive" includes the elderly who do not work and do not look for working. }\end{array}$ \\
\hline Age & $\begin{array}{l}\text { Age of the elderly in years. The elderly are divided into three groups namely, young } \\
\text { elderly (age 60-69), older elderly (age 70-79), oldest elderly (age } 80 \text { and above) }\end{array}$ \\
\hline Gender & Gender of the elderly (biological gender). \\
\hline Marital status & $\begin{array}{l}\text { The elderly are divided into two groups on the basis of their marital status namely, } \\
\text { married and non-married. The non-married category includes the elderly who are never } \\
\text { married, widowed, divorced, and separated. }\end{array}$ \\
\hline Ethnicity & $\begin{array}{l}\text { The study considers three categories for the ethnicity of elderly, including Sinhala, Tamil, } \\
\text { and Other. The category "Tamil" includes the elderly who belong to the Sri Lanka Tamil } \\
\text { and the Indian Tamil ethnic groups. The elderly who belong to the ethnic groups except } \\
\text { Sinhala and Tamil are identified under the "Other" category. }\end{array}$ \\
\hline Living sector & $\begin{array}{l}\text { The elderly who are living in areas controlled by the local government authorities are } \\
\text { categorized under the "urban" category, and the rest is under the "rural" category. }\end{array}$ \\
\hline Province & The province that an elderly belongs to. There are nine provinces in Sri Lanka. \\
\hline $\begin{array}{l}\text { Educational } \\
\text { qualification }\end{array}$ & $\begin{array}{l}\text { The highest educational qualification obtained by an elderly. There are four categories } \\
\text { of this variable. The category "primary" includes the elderly group schooled up to } \\
\text { either grade from one to six while the category "secondary" includes the elderly who } \\
\text { schooled up to either grade from seven to advanced level class. Also, the elderly group } \\
\text { with a degree, a post graduate degree, or a diploma is considered to be the group with } \\
\text { the highest educational qualification. The elderly who have never schooled are used as } \\
\text { the reference category. }\end{array}$ \\
\hline $\begin{array}{l}\text { Social security } \\
\text { receipts }\end{array}$ & $\begin{array}{l}\text { This shows that whether an elderly receives one or more of the payment categories of } \\
\text { pension, disability relief and Samurdhi benefits. }\end{array}$ \\
\hline Remittance receipts & $\begin{array}{l}\text { This shows that whether an elderly receives remittances either from local sources, } \\
\text { abroad, or both. }\end{array}$ \\
\hline $\begin{array}{l}\text { Gender of household } \\
\text { head }\end{array}$ & Gender of head of the household in which elderly are living. \\
\hline Health condition & $\begin{array}{l}\text { This variable explains whether an elderly is suffering from one or more of chronic } \\
\text { illnesses or disabilities concerned. }\end{array}$ \\
\hline $\begin{array}{l}\text { Indebtedness of living } \\
\text { household }\end{array}$ & $\begin{array}{l}\text { This indicates whether any member of the household in which an elderly is living is } \\
\text { indebted to one or more of the following parties: banks, finance companies, own place of } \\
\text { work, money lenders, retail outlets, and other selling and buying shops. }\end{array}$ \\
\hline wf percentage & $\begin{array}{l}\text { The number of members of a household whose age is greater than or equal to } 15 \text { years } \\
\text { and less than } 60 \text { years as a percentage of the household size of that particular household. }\end{array}$ \\
\hline
\end{tabular}

